\title{
Design Of Sugar Cane Ujice Evaporator With Spray-Cyclone As A New Breakthrough In Sugar Industry
}

\author{
Taufiq Immawan \\ Industrial Engineering, Faculty of Industrial Technology, \\ Universitas Islam Indonesia, Jl. Kaliurang Km 14,5 \\ Syakia Muflihat \\ Industrial Engineering, Faculty of Industrial Technology, \\ Universitas Islam Indonesia, Jl. Kaliurang Km 14,5
}

\begin{abstract}
In the sugar industry, the problems that occur not only in the factory but also in sugar cane land, namely a decrease in factory load because the age of the developing factory needs maintenance and replacement of the machine that must be adjusted. Therefore, it is necessary to make a breakthrough to maximize operations from land to factories. The breakthrough was made in the form of making a mobile evaporator that can support the business process of reengineering the production of sugar cane juice on the land. In addition, the problem encountered in the functional evaporator itself is the steam pressure setting that is not in accordance with the SOP, the results of brix are difficult to predict, cleaning of hard sugar juice catchers, cleaning of difficult heating bodies and too long evaporation process. The problem-solving process is conduct using the TRIZ method to get design specifications that are expected by the user. Improving and worsening contradiction matrix in the form of 3 attributes that are used, namely an effective process, easier temperature settings, and portable. The results from TRIZ provide several specific solutions for functional tools such as adopting the sugar juice input method into the heating body using spray and cyclone to create a more effective process, adding additional blowers to maintain heating temperature and evaporator dimensions that are suitable for mobile application. The solution obtained from TRIZ was applied in the manufacture of evaporators and experiments on these devices to produce sugarcane juice that meets quality standards. The initial volume of this experiment was 15 liters of sugar cane juice and the final volume was 7 liters. The initial Brix sugar cane juice is $23 \%$ and the final brix is $40 \%$
\end{abstract}

Keywords: Prototype, mobile, TRIZ, spray and cyclone.

\section{INTRODUCTION}

In previous research, a business research process has been carried out on several work stations with the output of a mobile engine design to optimize the work station [1]. Evaporator machine is a machine that is used to evaporate water at low temperatures and pressures so that it can reduce water content in a material that produces liquid sugar that is of high quality and durable. Based on a field survey at the Madukismo PG sugar mill, there were several problems encountered in the evaporation process at the evaporation station using the current evaporator machine.

Some of the problems that arise are regulating the vapor pressure of the feed (heater) not fulfilling the SOP, the unpredictable brix results, cleaning the difficult sugar juice catcher, cleaning the difficult heating body, the difficulty in regulating the incoming and outgoing sugar juice discharge, the air pressure in the heating body up and down and the evaporation process is too long so a new breakthrough is needed to produce a faster evaporation process, reduce costs and produce sugar juice that meets the standards and can adjust to the production 
process on the land [2]. According to research [3] the use of spray technology can help improve better separation rates. This method was adopted for the separation between water using artificial sea water with $3 \%$ salt content. The size of microdroplets and sprayed heat affects the performance of the device. Droplets with high heat flux density and superheat levels provide increased water evaporation. In the design improvements made [4] on honey-lowering machines using spray technology by fixing the nozzle, the smaller the size of the sprayed droplet, the faster the process. Therefore in this study will use spray-cyclon technology on the evaporator and conduct trials and improvements to the tools that have been made to determine the system, capacity, and results of the sugar juice that has been evaporated.

\section{Design}

The design is done by using the TRIZ method to solve problems that exist in the specifications applied. TRIZ (Theory of Rasheniya Izobretatelskikh Zadatch) or (Theory of Inventive Problem Solving) is a method used to solve creative problems based on logic and data [5]. The following is the result of the TRIZ method:

Table 1. Solution Design

\begin{tabular}{|c|c|c|c|c|c|c|}
\hline$C A$ & Improving & Worsening & $\begin{array}{l}\text { Inventive } \\
\text { Principles }\end{array}$ & Explanation & Application Ideas & Specific Solution \\
\hline 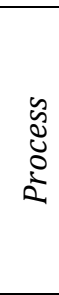 & $\begin{array}{l}\text { Loss of time } \\
\text { (25) }\end{array}$ & $\begin{array}{l}\text { Use of energy } \\
\text { by moving } \\
\text { object (19) }\end{array}$ & $\begin{array}{l}(35) \\
\text { Transform } \\
\text { ation }\end{array}$ & $\begin{array}{l}\text { Change the } \\
\text { evaporation system } \\
\text { / technique by } \\
\text { considering the } \\
\text { properties / factors } \\
\text { that influence } \\
\text { evaporation }\end{array}$ & $\begin{array}{l}\text { Replace the } \\
\text { evaporation system } \\
\text { in the evaporation } \\
\text { section }\end{array}$ & $\begin{array}{l}\text { Changing the sugar } \\
\text { juice input system } \\
\text { with shower nozzle } \\
\text { (cyclone) sprayers } \\
\text { with F75 gravity } \\
\text { type spray water } \\
\text { with } 1.5 \mathrm{~mm} \text { nozzle }\end{array}$ \\
\hline 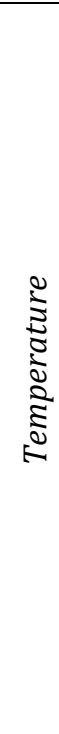 & $\begin{array}{l}\text { Temperature } \\
\text { (17) }\end{array}$ & $\begin{array}{l}\text { Use of energy } \\
\text { by moving } \\
\text { obj. (19) }\end{array}$ & $\begin{array}{l}15 . \\
\text { Dynamics }\end{array}$ & $\begin{array}{l}\text { Design the } \\
\text { properties of an } \\
\text { object, the } \\
\text { surrounding } \\
\text { environment or } \\
\text { process to find } \\
\text { conditions that are } \\
\text { more optimal and } \\
\text { divide an object or } \\
\text { system into parts } \\
\text { that are able to } \\
\text { cooperate with } \\
\text { each other }\end{array}$ & $\begin{array}{l}\text { Change the heating } \\
\text { system by adding a } \\
\text { set of heaters in the } \\
\text { form of a separate } \\
\text { artificial stove so } \\
\text { that it can produce } \\
\text { the desired } \\
\text { temperature output } \\
\left( \pm 90^{\circ} \mathrm{C}\right) \\
\text { and adding a device } \\
\text { in the form of a } \\
\text { blower to optimize } \\
\text { heating results, } \\
\text { where the heating } \\
\text { system serves to } \\
\text { regulate the } \\
\text { temperature to be } \\
\text { fed. }\end{array}$ & $\begin{array}{l}\text { Source of artificial } \\
\text { heating stove and } \\
\text { blower with air } \\
\text { speed of } 12 \mathrm{~m} / \mathrm{s} \text {. }\end{array}$ \\
\hline $\begin{array}{l}\frac{1}{8} \\
\frac{1}{0} \\
\frac{2}{0}\end{array}$ & $\begin{array}{l}\text { Adaptability } \\
\text { Versatility } \\
\text { (35) }\end{array}$ & $\begin{array}{l}\text { Volume of } \\
\text { moving } \\
\text { object (7) }\end{array}$ & $\begin{array}{l}15 . \\
\text { Dynamics }\end{array}$ & $\begin{array}{l}\text { Designing } \\
\text { evaporation tools } \\
\text { that can adjust to } \\
\text { the machine's } \\
\text { installation media, } \\
\text { namely a truck }\end{array}$ & $\begin{array}{l}\text { Associated with } \\
\text { changes in engine } \\
\text { size that can be run } \\
\text { and adjusted to the } \\
\text { truck so that the } \\
\text { production process } \\
\text { of sugar juice can } \\
\text { run directly when in } \\
\text { the sugar cane } \\
\text { plantation. }\end{array}$ & $\begin{array}{l}\text { The overall } \\
\text { dimensions of the } \\
\text { evaporation device } \\
\text { are } 65 \mathrm{~cm} \text { wide } \\
\text { and } 250 \mathrm{~cm} \text { high. } \\
\text { The evaporation } \\
\text { body has a volume } \\
\text { of } 400 \text { liters and a } \\
\text { storage body of } 15 \\
\text { liters, and a final } \\
\text { reservoir of } 10 \\
\text { liters. }\end{array}$ \\
\hline
\end{tabular}




\section{Design Part and Dimension}

\begin{tabular}{|l|ll|}
\hline \multicolumn{1}{|c|}{ Part } & \multicolumn{1}{c|}{ Dimension } \\
\hline \multirow{2}{*}{ Evaporation tube } & - & Diameter $=60 \mathrm{~cm}$ \\
& - & Tube height $=80 \mathrm{~cm}$ \\
& - & Chimney height $=20 \mathrm{~cm}$ \\
& - & Chimney diameter $=10 \mathrm{~cm}$ \\
& - & Evaporation cone height $=120 \mathrm{~cm}$ \\
\hline \multirow{2}{*}{ Input Pipe } & - & Pipe diameter $(1)=3 \mathrm{~cm}$ \\
& - & Pipe height $(1)=11 \mathrm{~cm}$ \\
& - & Pipe diameter $(2)=6 \mathrm{~cm}$ \\
Sugar Juice Tube & - & Pipe height $(2)=6 \mathrm{~cm}$ \\
\hline \multirow{2}{*}{ Foot buffer } & - & Diameter $=32 \mathrm{~cm}$ \\
& - & Height $=38,5 \mathrm{~cm}$ \\
\hline
\end{tabular}

The figure of the evaporator machine are as follows:

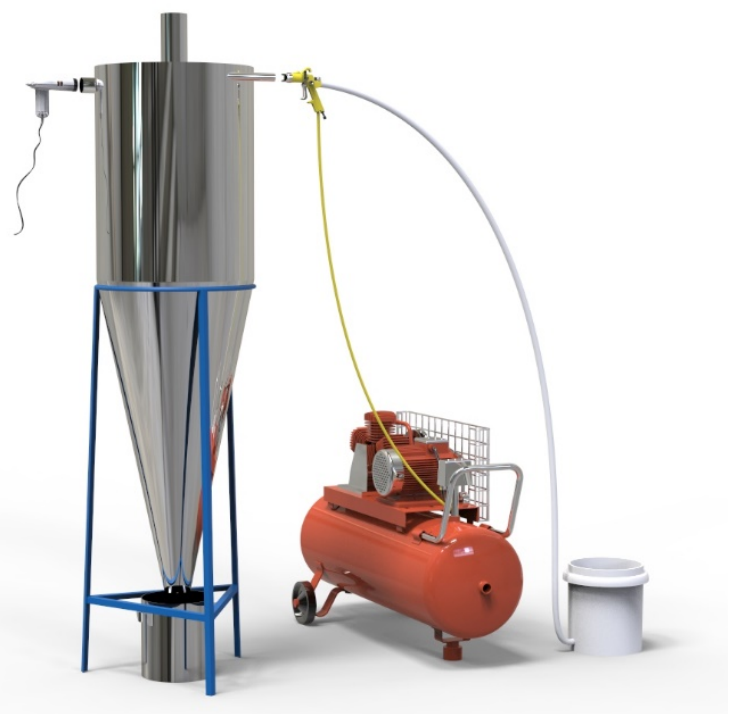

Figure 1. Evaporator machine

Evaporator engine testing is carried out in 1 experimental condition to determine whether the engine is designed and functioning according to its function. The trial was carried out using sugar cane with an initial volume of 15 liters with constant spray speed and constant heat and without the addition of any additives. The sugarcane grinding process lasts for 20 minutes, the heating and evaporation process lasts for 45 minutes. The initial Brix check is $23 \%$, then the juice is heated by using LPG for \pm 20 minutes to produce hot juice with a temperature of $100 \mathrm{o}$. In this heating process, the dirt from the sugar cane is lifted. The thing that must be considered is the time difference between the boiling time of the sugar juice and the lifting process to prevent the dirt from being mixed again. Brix sugar juice that has been heated is $25 \%$. Hot juice sprayed into the evaporation body on side 1 then hot steam which is also sprayed on the other side produces a cyclone model in the evaporation body. this process results in hot juice being spread over the entire surface of the evaporation body. In this model, the sugar juice that is sprayed together with hot steam will accelerate evaporation, then the particles in the sugar juice will separate. Particles with heavier masses will fall down and particles with smaller masses will evaporate toward the chimney made on the upper side of the evaporation body, 
not only that this method can kill the house from the heating and separate the pure sugar juice and impurities. From the experiment, the sugar juice was produced with a brix that was better and thicker than before, where the measurement of $40^{\circ}$ brix was measured using a manual refractometer and a volume of 7 liters of juice. This process removes the water content of the sugar juice so that it produces juice with increased concentration.

\section{CONCLUSION}

1. Main dimensions of evaporator engine: Diameter of evaporation tube $60 \mathrm{~cm}$, chimney diameter $10 \mathrm{~cm}$ height of chimney $20 \mathrm{~cm}$, pipe height $111 \mathrm{~cm}$, pipe diameter $13 \mathrm{~cm}$, pipe height $8 \mathrm{~cm}$, pipe diameter $26 \mathrm{~cm}$, height cone evaporation $120 \mathrm{~cm}$, the height of the foot support is $150 \mathrm{~cm}$, the diameter of the room is $32 \mathrm{~cm}$, the height of the room is 38.5

2. The results of the trial of the sugarcane juice evaporator are: the rate of sugar juice evaporation is 0.32 liter / min, evaporating water by $53 \%$, the resulting brix juice is $40 \mathrm{o}$

3. For the application of industrial level evaporators, it is necessary to adjust the flow of juice, the size of the spray particles and the temperature at evaporation.

\section{References}

N. P. Shafira, " Proposed reengineering of business processes in the case study sugar industry PG Madukismo," Universitas Islam Indonesia, Yogyakarta, 2018.

M. N. Hizam, " Redesign of sugar cane juice evaporation devices using the TRIZ method," Universitas Islam Indonesia, Yogyakarta, 2018.

W. Gao, C. Li, C. Xu and D. Wang, "Experimental study on water separation process in a novel spray flash vacuum evaporator with heat-pipe," Desalination, pp. 39-47, 2016.

A. Fauzan, " Engineering of the fogging system on honey water-lowering machines," GAMMA, vol. 1, no. 0, pp. 125127,2006

R. Tiafani, A. Desrianty and C. SW, " Design of improvement of children's walker (baby walker) using the theory of inventive problem solving (TRIZ) method," Jurnal Online Institut Teknologi Nasional, vol. 1, no. 0, pp. 70-79, 2014. 